\title{
REVIEW
}

\section{Scientific approaches to address challenges in coastal management}

\author{
A. M. Nobre* \\ Institute of Marine Research (IMAR), Centre for Ocean and Environment, New University of Lisbon. FCT, Campus da Caparica, \\ 2829-516 Caparica, Portugal \\ Present address: SIMTEJO - Saneamento Integrado dos Municípios do Tejo e Trancão, SA, \\ Avenida Defensor de Chaves, 45, 2 ${ }^{\circ}$ 1000-112 Lisboa, Portugal
}

\begin{abstract}
Anthropogenic activity has a negative impact on many coastal ecosystems, compromising the significant direct and indirect socio-economic benefits provided in these areas. Maintaining activities that depend on coastal zones while preserving the ecological state of the ecosystems represents a management challenge. Management of coastal zones requires scientifically based knowledge, due to the complexity of the ecological processes which occur in these ecosystems and because of interaction with the socio-economic system. The effectiveness of coastal management instruments and programmes needs to be evaluated to determine the success of adopted measures and to establish improved goals. Some of the research areas that can support coastal management include marine spatial planning, ecological modelling, development of tools to communicate science to managers, and interaction between coastal ecosystems and socio-economics. This paper reviews management instruments to address coastal zone problems and of some research areas to support management.
\end{abstract}

KEY WORDS: Integrated coastal zone management $\cdot$ Ecosystem-based management $\cdot$ Marine spatial planning $\cdot$ Ecosystem model · Integrated environmental assessment · Differential drivers-pressurestate-impact-response approach · Ecological economics

Resale or republication not permitted without written consent of the publisher

\section{INTRODUCTION}

Coastal ecosystems generate goods and services with a high economic value (Ledoux \& Turner 2002, Egoh et al. 2007, Rönnbäck et al. 2007, Koch et al. 2009). As a result of the ecological importance of coastal zones for human activities, a large percentage (around $40 \%$ ) of the world population and of the world's economic activities (around $61 \%$ of the gross world product; MA 2005, Martínez et al. 2007) are concentrated in a $100 \mathrm{~km}$-wide strip along the coast. Increasing human pressure on coastal zones is causing degradation (Boissonnas et al. 2002, Halpern et al. $2008 \mathrm{a}, \mathrm{b})$ and consequently a decrease in the benefits that these ecosystems deliver (Bowen \& Riley 2003, MA 2005, Costanza \& Farley 2007, Lester et al. 2010). The main threats posed by humans to coastal areas include loss of natural habitats, biodiversity loss, decline in water quality, vulnerability to global changes such as predicted sea level rise, increased negative impacts of coastal disasters, competition for space and seasonal variations in pressure (Ehler et al. 1997, Fabbri 1998, Humphrey et al. 2000, MA 2005, Costanza \& Farley 2007, Defeo et al. 2009). Sustainable management of coastal zones thus constitutes a challenge for coastal stakeholders.

Over the past few decades, policy makers worldwide have defined policy and legislative instruments to address coastal zone problems (Clark 1996, Borja 2006, Ducrotoy \& Elliott 2006). One of the more widely known and applied is the integrated coastal zone management (ICZM) approach (Cicin-Sain \& Knecht 1998). A complementary coastal management approach, known as ecosystem-based management (EBM), highlights the need to (1) consider the cumulative effects within and across ecosystems, (2) use the best avail- 
able information about a given ecosystem and adapt to emerging knowledge, and (3) consider both human and natural dimensions as key aspects in the management of marine resources and functions (Fluharty 2005, Murawski 2007, Borja \& Collins 2009, Douvere \& Ehler 2009, Forst 2009, Queffelec et al. 2009, Lester et al. 2010, Tallis et al. 2010). The development, implementation and output evaluation of coastal management instruments and programmes must be supported by scientifically based knowledge (Martínez et al. 2007, Lester et al. 2010). Managers and policy makers require analytical and assessment methodologies to (1) generate understanding about coastal ecosystems and their interaction with the socio-economic system, and (2) synthesise research outcomes into useful information in order to define effective responses and evaluate previously adopted actions (McNie 2007, Stanners et al. 2008).

The objectives of the present paper are to review (1) the main management instruments, such as ICZM and EBM, used to address coastal zone problems and (2) some of the research areas that can contribute to coastal management, namely marine spatial planning, ecological modelling, tools to communicate science to managers, and interaction between coastal ecosystems and socio-economics.

\section{ADDRESSING EMERGING COASTAL ZONE PROBLEMS}

\section{Integrated coastal zone management}

ICZM is defined as a dynamic management process that brings together the human and the ecological dimensions to promote the sustainable use, development and protection of coastal zones (Clark 1996, Olsen 2003, Forst 2009). Managers worldwide have adopted ICZM in different contexts: (1) either at national or local levels, as exemplified by NRMMC (2006) and Lewis et al. (1999), respectively; (2) following a top-down approach or based on a community-based initiative (Cicin-Sain \& Knecht 1998, Lewis et al. 1999, Belfiore 2000, Kearney et al. 2007); (3) to address specific environmental problems in coastal zones or to manage coastal vulnerability to natural hazards and climate change (Clark 1996, Krishnamurthy et al. 2008).

Table 1 presents an overview of worldwide coastal management initiatives. Although such a synthesis is reductionist with regard to coastal management efforts, it illustrates that ICZM initiatives appeared about 4 decades ago and that some countries are currently adopting new programmes. Clark (1996), Kay et al. (1997), Cicin-Sain \& Knecht (1998), Hale (2000), Eremina \& Stetsko (2003), PEMSEA (2003), Lau (2005), Cao \& Wong (2007) and Krishnamurthy et al. (2008) provided detailed ICZM case studies developed worldwide, and Cruz \& McLaughlin (2008) compared different marine policies across different countries. The early USA-concerted coastal management efforts are stable and in a mature stage (Hershman et al. 1999, Hale 2000, Gibson 2003). Hershman et al. (1999) and Humphrey et al. (2000) described the key features for its success and its shortcomings. Coastal management programmes on a European scale are more recent (Humphrey et al. 2000, Shipman \& Stojanovic 2007). The various European Union (EU) policies and directives emerged as complementary instruments, the most important being (Borja 2006, Ducrotoy \& Elliott 2006, 2008, Borja et al. 2010) the Water Framework Directive (WFD) of 2000, the ICZM recommendation of 2002 and the Marine Strategy Framework Directive (MSFD) of 2008. Rupprecht Consult \& IOI (2006) provided a synthesis of some of the EU policy application in each member state. Table 1 shows a brief sample of the programmes adopted within the EU at 3 scales: (1) legislation and policies applied at the EU level, (2) programmes to be implemented at transnational level for joint management of European seas (not exclusively within EU member states), and (3) legislation mainly developed at the national level, not necessarily to address EU programmes. The individual EU member states have different approaches to coastal management with a variety of coastal management initiatives and legislations (Gibson 2003, Shipman \& Stojanovic 2007). In Spain, for instance, complementary to the Coastal Law, several autonomous communities have specific regional programmes of action (Sardá et al. 2005). In the UK, ICZM is characterised by local and regional coastal management programmes, corresponding to a number of administrative bodies with interest in coastal management (Stojanovic \& Ballinger 2009). Several initiatives are being taken for the development of an ICZM programme for the UK in response to the EU ICZM Recommendation of 2002, namely the Marine and Coastal Access Act of 2009 (ATKINS 2004, Stojanovic \& Ballinger 2009, DEFRA 2010). For detailed coastal management initiatives within and across EU member states refer to van Alphen (1995), Barragán Muñoz (2003, 2010), Pickaver (2003), Veloso-Gomes \& Taveira-Pinto (2003), Anker et al. (2004), Taveira-Pinto (2004), Scottish Executive (2005), Enemark (2005), Smith \& Potts (2005), DOENI (2006), Rupprecht Consult \& IOI (2006), WAG (2007), Deboudt et al. (2008), DEFRA (2008, 2010) and Stojanovic \& Ballinger (2009).

For individual ICZM programmes to evolve, comprehensive evaluations are required. It is important that ICZM programme output evaluation is combined with 'state-of-the-coast' information to show, for instance, whether new programme goals may be needed as well as to allow an ICZM programme to evolve to an 
Table 1. Overview of major integrated coastal zone management (ICZM) initiatives worldwide

\begin{tabular}{|c|c|c|c|c|}
\hline \multirow{2}{*}{$\begin{array}{l}\text { First initiatives } \\
\text { Australia }\end{array}$} & & & \multicolumn{2}{|c|}{ Recent initiatives } \\
\hline & & & 2003 & $\begin{array}{l}\text { Framework for a National Cooperative } \\
\text { Approach to ICZM }\end{array}$ \\
\hline \multirow[t]{2}{*}{ South Australia } & 1972 & Coast Protection Act & 1994 & Environment Protection (Marine) Policy \\
\hline & 1979 & & 2000 & Environment Protection (Water Quality) Policy \\
\hline Queensland & & & 1995 & Coastal Protection and Management Act \\
\hline \multicolumn{2}{|l|}{ Tasmania } & & 1996 & State Coastal Policy \\
\hline \multicolumn{2}{|l|}{ Victoria } & & 1995 & Coastal Management Act 1995 \\
\hline \multicolumn{2}{|l|}{ Western Australia } & & 2001 & CZM Policy \\
\hline Brazil & 1988 & $\begin{array}{l}\text { Law 7661, establishes the } \\
\text { National CZM Plan }\end{array}$ & 2004 & $\begin{array}{l}\text { Decree 5300, regulates the National CZM Plan } \\
\text { and other instruments for ICZM }\end{array}$ \\
\hline \multirow[t]{3}{*}{ Canada } & & & 1991 & Atlantic Coastal Action Program (ACAP) \\
\hline & & & 1997 & Oceans Act \\
\hline & & & 2002 & Oceans Strategy \\
\hline \multirow[t]{3}{*}{ PR China } & 1982 & $\begin{array}{l}\text { Marine Environment Protection } \\
\text { Law of the PR of China }\end{array}$ & 1995 & Measures of management of marine natural reserves \\
\hline & & & 2001 & Measures of management on utilisation of sea areas \\
\hline & & & 2002 & Marine functional zonation scheme \\
\hline \multirow{4}{*}{ European Union } & & & 1996 & Demonstration programme on ICZM \\
\hline & & & 2000 & Water Framework Directive (2000/60/EC) \\
\hline & & & 2002 & $\begin{array}{l}\text { ICZM Recommendation 2002/413/EC for member } \\
\text { states to adopt a national strategy on ICZM. }\end{array}$ \\
\hline & & & 2008 & Marine Strategy Framework Directive (2008/56/EC) \\
\hline \multirow[t]{2}{*}{ Baltic Sea } & & & 2003 & HELCOM ICZM Recommendation 24/10 \\
\hline & & & 2007 & HELCOM Baltic Sea Action Plan \\
\hline \multirow[t]{3}{*}{ France } & 1975 & $\begin{array}{l}\text { Coastal Conservancy } \\
\text { (Law of } 10 \text { July) }\end{array}$ & 2002 & $\begin{array}{l}\text { Reform of the Coastal Conservancy's mission } \\
\text { (law of } 27 \text { February) }\end{array}$ \\
\hline & 1983 & $\begin{array}{l}\text { Marine Area Zoning Plan } \\
\text { (SMVM) (law 83/8) }\end{array}$ & & \\
\hline & 1986 & $\begin{array}{l}\text { Planning, protection, and } \\
\text { development of coastal space }\end{array}$ & & \\
\hline \multicolumn{2}{|l|}{ Poland } & & 1991 & $\begin{array}{l}\text { Poland's Act on Marine Areas and on } \\
\text { Maritime Administration }\end{array}$ \\
\hline \multirow[t]{5}{*}{ Portugal } & & & 1993 & $\begin{array}{l}\text { Coastal strip management plans (POOC) } \\
\text { (Decree-Law 309/93) }\end{array}$ \\
\hline & & & 1998 & $\begin{array}{l}\text { Portuguese Coastal Strip Strategy } \\
\text { (Minister Council Resolution 86/98) }\end{array}$ \\
\hline & & & 2001 & $\begin{array}{l}\text { National Strategy for Nature Conservation } \\
\text { (Minister Council Resolution 152/2001) }\end{array}$ \\
\hline & & & 2006 & $\begin{array}{l}\text { National Strategy for the Sea } \\
\text { (Minister Council Resolution 163/2006) }\end{array}$ \\
\hline & & & 2009 & $\begin{array}{l}\text { National Strategy for the ICZM } \\
\text { (Minister Council Resolution 82/2009 }\end{array}$ \\
\hline Spain & 1988 & Coast Law & 2007 & Strategy for the Sustainability of the Coast \\
\hline \multirow[t]{2}{*}{ Wadden Sea } & 1978 & $\begin{array}{l}\text { Trilateral Wadden Sea } \\
\text { Cooperation }\end{array}$ & 1997 & Wadden Sea Plan \\
\hline & 1982 & Joint declaration & & \\
\hline \multicolumn{2}{|l|}{ IOC member states } & & 1997 & $\begin{array}{l}\text { Integrated Coastal Area Management (ICAM) } \\
\text { programme adopted by the Intergovernmental } \\
\text { Oceanographic Commission (IOC) }\end{array}$ \\
\hline \multirow[t]{2}{*}{ New Zealand } & & & 1994 & Coastal Policy Statement (NZCPS) \\
\hline & & & 2008 & Proposed review of NZCPS \\
\hline \multirow[t]{5}{*}{ USA } & 1948 & $\begin{array}{l}\text { Federal Water Pollution } \\
\text { Control Act }\end{array}$ & 2000 & Oceans Act \\
\hline & 1972 & CZM Act & & \\
\hline & 1972 & Clean Water Act & & \\
\hline & 1987 & $\begin{array}{l}\text { National Estuary Program } \\
\text { (NEP), established by the }\end{array}$ & & \\
\hline & & Water Quality Act & & \\
\hline
\end{tabular}


improved version (Olsen et al. 1997, Hershman et al. 1999, Stojanovic et al. 2004, Billé, 2007). However, most of the evaluation efforts focus on measuring the evolution of the ICZM process outputs (Olsen 2003, Pickaver et al. 2004, Stojanovic et al. 2004, Billé 2007 , Gallagher 2010). Worldwide and independent of the degree of maturity of the ICZM process, measurements of its effectiveness are lacking, i.e. of the consequent changes in the state of the coastal systems, its resources and associated benefits (Knecht et al. 1996, 1997, Kay et al. 1997, Olsen et al. 1997, Hershman et al. 1999, Humphrey et al. 2000, Billé 2007, McFadden 2007). Among other reasons, the difficulty involved in selecting criteria to measure the system's performance stands out. The difficulty stems from (1) an unclear set of ICZM objectives, (2) the complexity of coastal ecosystems and (3) data requirements (Burbridge 1997, Stojanovic et al. 2004). Problems defining a specific set of indicators for all coastal systems are greater at the national or broader level due to the different susceptibility and resilience of ecosystems, the pressures these are subject to and the issues to be tackled (Pickaver et al. 2004). The diversity of coastal systems and of the pressures on them requires flexibility in the development and implementation of ICZM programmes, which in turn calls for flexible assessment approaches (Humphrey et al. 2000, Olsen 2003). Table 2 presents a synthesis of some studies that evaluated the effectiveness of ICZM programmes.

The development of indicators and tools to evaluate ICZM at different levels is ongoing, as analysed by Hoffmann (2009). For instance, Cordah Ltd (2001) and Belfiore et al. (2006) consolidated a suite of indicators developed worldwide for ICZM. At the European level, assessment tools are also being developed in a collab- orative effort between managers and the research community (Bowen \& Riley 2003, Ehler 2003, Ducrotoy \& Elliott 2006, Kiousopoulos 2008, Diedrich et al. 2010). An important feature of this effort is the inclusion of measurable indicators as common tools to quantify both the progress of implementation of ICZM and the sustainable development of the coastal zone (Breton 2006). These worldwide efforts are valuable contributions towards making the assessment of the evolution of coastal zones the standard rather than the exception in the ICZM process.

\section{Ecosystem-based management}

Complementary to ICZM, EBM emerged recently as a scientific consensus that highlights (1) the importance of considering the interactive and cumulative impacts of the range of activities that act on the coastal ecosystems and (2) the definition of strategic objectives across those activities for their sustainable management (Browman \& Stergiou 2005, Murawski 2007, Halpern et al. 2008a, Forst 2009, McLeod \& Leslie 2009). The concept of the ecosystem-based approach first appeared in the 1970s, not specifically related to coastal zones (Slocombe 1993). Grumbine (1994) and Slocombe (1998) reviewed the origins and principles of EBM and provided lessons for implementing it. An important feature that both authors highlighted is that EBM is about integrating environment and human activities. They emphasised that in the real systems, humans are within, rather than separated from, nature. Slocombe (1998) suggested that an effective EBM (1) starts with a synthesis of information for future research and management, (2) monitors features to fol-

Table 2. Examples of evaluation of the effectiveness of Integrated Coastal Zone Management (ICZM) programmes

\begin{tabular}{|c|c|c|}
\hline Programme/domain & Description & Source \\
\hline $\begin{array}{l}\text { Perceptions of the } \\
\text { performance of } 24 \text { state CZM } \\
\text { programmes in the USA } \\
(1993-1995)\end{array}$ & $\begin{array}{l}\text { Evaluation was based on a survey of perceived performance } \\
\text { on } 4 \text { major coastal management issues: (1) protection of coastal } \\
\text { resources; (2) management of coastal development; (3) improved } \\
\text { public access; and (4) reduction of losses due to coastal hazards. }\end{array}$ & Knecht et al. (1996) \\
\hline $\begin{array}{l}\text { US National CZM } \\
\text { effectiveness study } \\
(1995-1997)\end{array}$ & $\begin{array}{l}\text { Objective is to determine success of } 5 \text { of the core objectives of } \\
\text { the USA CZM Act of 1972: (1) protection of estuaries and } \\
\text { coastal wetlands; (2) protection of beaches, dunes, bluffs and } \\
\text { rocky shores; (3) provision of public access to the shore; }(4) \\
\text { revitalisation of urban waterfronts; and (5) accommodation } \\
\text { of seaport development. } \\
\text { Although based on limited data, it evaluates programme success } \\
\text { based on 'on-the-ground outcomes'. }\end{array}$ & Hershman et al. (1999) \\
\hline $\begin{array}{l}\text { Tampa Bay Estuary } \\
\text { Program (USA) }\end{array}$ & $\begin{array}{l}\text { The programme includes the definition of specific goals to } \\
\text { address the identified issues to be managed. Quantitative criteria } \\
\text { were selected to evaluate the programme outcomes. These include } \\
\text { e.g. areal extent of seagrasses and populations of birds. }\end{array}$ & Lewis et al. (1999) \\
\hline
\end{tabular}


low changes, (3) uses local knowledge and (4) is practical, i.e. if resources are limited it needs to focus research on knowledge that is meaningful to management. The definition of operational goals is an important challenge for EBM implementation, according to Slocombe (1998). In one of the first references to EBM for coastal zones, Imperial \& Hennessey (1996) identified the US National Estuary Program (NEP) as a promising ecosystem-based approach to manage estuaries. The particularity of NEP is to focus on solutions for problems identified in each estuary (Imperial \& Hennessey 1996). For each estuary, a comprehensive conservation and management plan is implemented which contains an action plan to address the identified problems and a monitoring programme to measure the effectiveness of activities. Furthermore, the plan sets the funding and the institutional context for the implementation of the estuarine programmes. At the European level, there are also several examples of EBM, for example for the Baltic Sea, North Sea and Wadden Sea (Enemark 2005, HELCOM 2007, Ducrotoy \& Elliott 2008). In Canada, the Atlantic Coastal Action Program (ACAP) is an ecosystem and community-based approach to integrate planning and management of the environment, which has unique features such as power sharing among stakeholders (McNeil et al. 2006). Environment Canada launched the programme in 1991, and the process consists of development and implementation of management plans, partnership building, local involvement and action and scientific research to improve and maintain the environmental integrity of coastal communities (McNeil et al. 2006). The ACAP established an alternative process to environmental and socio-economic management of coastal zones involving, at the beginning of the process, interested stakeholders in identifying problems and solutions. The evaluation of ACAP focuses on the environmental results and appraises the measures adopted and the pressures avoided, e.g. area of enhanced wildlife habitat or weight of mercury eliminated from waste streams. According to Environment Canada, the ACAP is effective on an ecosystem basis (McNeil et al. 2006).

\section{SCIENCE FOR COASTAL MANAGEMENT}

Management of coastal ecosystems requires interaction among managers and researchers of a range of disciplines, due to the complexity of the phenomena occurring in these systems (Fabbri 1998, Ducrotoy \& Elliott 2006). Research must be problem-oriented and the outputs translated into meaningful information for managers (Nobre et al. 2005, Dennison 2008, Hoffmann 2009). The enhanced understanding that scientific methodologies provide can be particularly useful in conflict-resolution processes inherent to coastal management (Fabbri 1998, McCreary et al. 2001). The development of integrative tools requires the interaction of all stakeholders (Cicin-Sain \& Knecht 1998, Van Kouwen et al. 2008) to ensure that (1) tools address relevant issues for coastal management and (2) managers can use the tools and their outputs.

Overall, ecosystem-based tools capable of providing insights into complex ecological processes and interaction with socio-economic systems are valuable to support the sustainable use of highly impacted coastal zones. The most commonly applied tools include (CicinSain \& Knecht 1998, Neal et al. 2003, Crowder \& Norse 2008, Nobre \& Ferreira 2009, Seim et al. 2009): (1) datagathering tools such as on-the-ground water quality sensors, radar systems and satellite imagery; (2) databases, georeferenced or not; (3) modelling tools, such as catchment and coastal ecosystem modelling; (4) geographical information systems (GIS) and remote sensing, including habitat mapping and habitat suitability; (5) marine spatial planning (MSP); (6) participatory work with stakeholders; (7) integrated environmental assessment, benefit-cost studies and economic valuation. The aim of these tools is to provide information for the decision-making process or its evaluation and not to replace decision makers (Van Kouwen et al. 2008).

Among the several research areas that support coastal management, I discuss the following: (1) MSP, (2) ecological modelling for simulation of management scenarios, (3) development of tools to communicate science to managers and (4) interaction between coastal ecosystems and socio-economics.

\section{Marine spatial planning}

MSP is a decision-making tool to support EBM implementation (Douvere 2008). MSP focuses on planning the multiple uses of the coastal and marine ecosystems and resolving conflicting interests and policies, allowing for an efficient zoning of the coastal and marine areas (Douvere 2008, Ehler \& Douvere 2009). The overall aim is to maintain the goods and services provided by marine ecosystems, which implies considering ecological principles for ecosystem function analysis (Crowder \& Norse 2008, Foley et al. 2010). There are several MSP case studies worldwide, and among the most comprehensive and long-lasting is the zoning scheme in Australia's Great Barrier Reef Marine Park (Day 2002). Douvere et al. (2007), Douvere (2008), Ardron et al. (2008) and Douvere \& Ehler (2010) have reviewed MSP case studies. At the European level, there are several drivers for MSP, primarily the EU legislation on conservation (Douvere 2008). In 2008, the European Commission published the 
'Roadmap for Maritime Spatial Planning' (EC 2008b) for MSP implementation at national and European levels. The process of coastal and marine zoning involves the use of other tools, such as databases for data assimilation, and GIS for spatial data analysis and production of maps which identify conflicting and compatible water uses (Douvere et al. 2007, Cömert et al. 2008). Ehler \& Douvere (2009) and Foley et al. (2010) provided, respectively, a detailed stepwise approach and the key elements for MSP implementation.

\section{Ecological modelling}

Ecological modelling is recognised as an important tool for coastal management that can contribute to understanding coastal ecosystem processes and simulate management scenarios (Turner 2000, Fulton et al. 2003, Greiner 2004, Hardman-Mountford et al. 2005, Murawski 2007, Forst 2009, Nobre et al. 2010a). Scenario testing can help managers design the most effective measures for attaining their goals. An understanding of the cumulative impacts of natural and anthropogenic pressures on coastal ecosystem state, and on the goods and services these areas provide is crucial for coastal management (Halpern et al. 2008a). Modelling approaches that are able to simulate the cumulative impacts of multiple coastal activities are still at an early stage of development (Fulton et al. 2003, Ferreira et al. 2008, Nobre et al. 2010a). An example is the multilayered ecosystem model that combines the simulation of the biogeochemistry of a coastal ecosystem with the simulation of its main forcing functions, such as catchment loading and aquaculture activities (Nobre et al. 2010a). Such models are, for instance, important for the determination of ecological carrying capacity required for the sustainable expansion of aquaculture (Dempster \& Sanchez-Jerez 2008, Ferreira et al. 2008, Soto et al. 2008). The outcomes of these models illustrate the usefulness of this approach for assisting the development of an ecosystem approach to aquaculture, as advocated by the FAO (FAO 2007, Soto et al. 2008).

Ecological models can be particularly useful if managers are engaged in the development process; this requires that the modelling team explains the model capabilities and limitations to managers and that the managers detail their requirements to the modelling team.

\section{Tools to communicate science to managers}

Integration and synthesis of complex knowledge from different disciplines into useful information for coastal managers and the public at large is a progress- ing and challenging field to environmental scientists (Harris 2002, McNie 2007, Cheong 2008). Integrated environmental assessment (IEA) methodologies can enhance communication between scientists and policy makers, since those methodologies aim to present an interdisciplinary synthesis of scientific knowledge (Tol \& Vellinga 1998, Harris 2002). Ecological modelling in particular can benefit from integration with IEA methodologies to distil the outcomes of complex models into useful information for managers (Nobre et al. 2005). Because the methodology involves human interpretation, one of the IEA caveats is subjectivity and dependence on the analyst's point of view (Tol \& Vellinga 1998).

The drivers-pressure-state-impact-response (DPSIR) is a well-known IEA framework (Peirce 1998) used to communicate science to coastal managers and in particular to bridge the science-management scales gap (Elliott 2002). A recent adaptation of the DPSIR, named Differential DPSIR ( $\triangle$ DPSIR), provides a framework to evaluate previously adopted policies and management scenarios, in order to detect symptoms of the overuse and misuse of coastal ecosystems (Nobre 2009). The overall objectives of the $\triangle$ DPSIR framework are to assess changes in coastal ecosystems and benefits generated due to management actions or scenarios.

At the EU level, several tools are being developed, specifically to support implementation of coastal-management related legislation and policy (Ducrotoy \& Elliott 2006). Specific examples include: (1) GIS as a decision support tool to be used in the development of the National Strategy for ICZM of the Catalan coast following the EU recommendation (Sardá et al. 2005); (2) GIS use for division of ecosystems into homogenous management units as required by the WFD (Ferreira et al. 2006, Balaguer et al. 2008); and (3) methods for classification of the WFD elements to evaluate ecosystem status for coastal and transitional waters (EC 2008a). Borja et al. (2008) reviewed at the global level the existing integrative assessment tools capable of supporting recent legislation developed in several nations to address ecological quality or integrity.

\section{Interaction between coastal ecosystems and socio-economics}

Understanding the linkages between natural and anthropogenic systems is crucial for ICZM and EBM (Turner 2000, Westmacott 2001, Boissonnas et al. 2002, Bowen \& Riley 2003, Cheong 2008). Firstly, the aim of ICZM is to promote the sustainable development of coastal ecosystems, including both ecological and socio-economic components. Secondly, coastal management and planning must account for the 'costs' of 
resource degradation. Finally, the measurement of the effectiveness of coastal management initiatives must screen not only the consequent changes in the ecological state of the ecosystem but also changes in the economic benefits and social welfare generated in coastal areas. In particular, economic valuation (using market and non-market methods) is crucial to account for ecosystem goods and services in decision making (Boissonnas et al. 2002, Lal 2003, Farber et al. 2006, Costanza \& Farley 2007).

The DPSIR approach, described in the previous section as a tool to communicate science to managers, also provides a conceptual scheme of how socio-economic activities interact with natural systems (Luiten 1999, Ledoux \& Turner 2002, Bowen \& Riley 2003, Bidone \& Lacerda 2004, Scheren et al. 2004, Hofmann et al. 2005, Cheong 2008, Nobre 2009). In simple terms, the DPSIR establishes the link between human activities ('drivers'), corresponding loads ('pressures'), resulting changes of the 'state' of the ecosystem (i.e. the 'impact') and the actions adopted by the coastal managers and decision makers ('response'). The $\triangle$ DPSIR further develops the general DPSIR approach. The key feature of the $\triangle \mathrm{DPSIR}$ is to provide an explicit link between ecological and economic information related to the use and management of a coastal ecosystem within a specific timeframe (Nobre 2009). The application of the $\triangle \mathrm{DPSIR}$ is illustrated by several case studies that use different datasets and scales of analysis. Nobre (2009) exemplified how this methodology can support the strategic management of natural resources in a coastal lagoon from both ecological and economic perspectives. In that case study, the $\triangle$ DPSIR was used to analyse the developments in a southwest European coastal lagoon between 1985 and 1995. Nobre et al. (2010b) illustrated the application of the $\triangle$ DPSIR for the ecological-economic assessment of aquaculture options at the farm level. A detailed dataset on the environmental and economic performance of an abalone farm located in South Africa was used. The case study consisted of assessing the ecological-economic effects of the abalone-seaweed integrated multitrophic aquaculture (IMTA) on the farm's performance and the corresponding environmental externalities.

The economic component must be included in dynamic ecological models in order to simulate the feedback between ecological and human systems (Bockstael et al. 1995, Nobre et al. 2009). Insights provided by the outcomes of such modelling tools are important for coastal management. For instance, with limited resources, it is important to prioritise actions that bring larger benefits to the public and at the same time allow the development of private activities. First attempts to integrate the ecological and economic models date back to the 1960s (Westmacott 2001). Inte- grated ecological-economic modelling is an evolving discipline that has increased recently (Drechsler et al. 2007). Several difficulties exist, such as the difference in scales at which these 2 systems are normally simulated or analysed (Nijkamp \& van den Bergh 1997, Turner 2000, Drechsler \& Watzold 2007, Nobre et al. 2009). Existing efforts to integrate ecological and economic models include the MARKET model, which dynamically couples the ecological and economic components of aquaculture production (Nobre et al. 2009). This model was applied to simulate shellfish production in a Chinese bay under different assumptions for price and income growth rates and the maximum area available for shellfish cultivation (Nobre et al. 2009). The simulation of the feedbacks between the ecological and economic systems supported the dynamic analysis of (1) the demand for aquaculture products, (2) economic production and cost-limiting factors, (3) the growth of aquatic resources, (4) interactions with environmental conditions and (5) the spatial limitations of culture in coastal ecosystems (Nobre et al. 2009). As any modelling exercise, the MARKET model has limitations; the most relevant is that the deterministic nature of the model cannot integrate the random nature of the economic agents (Nobre et al. 2009). As a consequence, the applicability of this model is limited to obtaining general trends by means of scenario simulations.

\section{CONCLUDING REMARKS}

The effective integration of science with management is important to improve policy formulation and policy making and thus for meeting both environmental and development needs and goals (Slocombe 1993, Peirce 1998, Turner 2000, Cheong 2008). It is important to define evaluation criteria in the development of management programmes and to include the relevant variables for managers and resource users in the modelling frameworks. This implies early interaction followed up by iterative communication between researchers, stakeholders with a management role and users of the goods and services of an ecosystem. Research into the ecological and economic assessment of coastal ecosystems is critical because of (1) the importance of, and high demand for, coastal zones, (2) the symptoms of overuse and misuse of these ecosystems and (3) the need for methodologies to evaluate the outcomes of coastal management initiatives and to support coastal planning. A particular area where efforts need to be increased is the development of methodologies to assess the impacts of the ICZM initiatives on coastal ecosystems (Olsen et al. 1997), including the changes in the benefits these generate. 
Acknowledgements. I thank 3 anonymous reviewers for their valuable comments on an earlier draft. This work was partially supported by the Portuguese Foundation for Science and Technology (FCT) PhD scholarship (SFRH/BD/25131/ 2005) to A.M.N. Open Access for the Theme Section on Coastal Zone Management is sponsored by the Marine Alliance for Science and Technology for Scotland (MASTS) Coastal Zone Joint Research Theme.

\section{LITERATURE CITED}

Anker HT, Nellemann V, Sverdrup-Jensen S (2004) Coastal zone management in Denmark: ways and means for further integration. Ocean Coast Manag 47:495-513

> Ardron J, Gjerde K, Pullen S, Tilot V (2008) Marine spatial planning in the high seas. Mar Policy 32:832-839

ATKINS (2004) ICZM in the UK: a stocktake. Report commissioned by UK Government, Department for Environment Food and Rural Affairs (Defra) with the Devolved Administrations. Queen's Printer and Controller of HMSO, Norwich

Balaguer P, Sardá R, Ruiz M, Diedrich A, Vizoso G, Tintoré J (2008) A proposal for boundary delimitation for integrated coastal zone management initiatives. Ocean Coast Manag 51:806-814

Barragán Muñoz JM (2003) Coastal zone management in Spain (1975-2000). J Coast Res 19:314-325

Barragán Muñoz JM (2010) Coastal management and public policy in Spain. Ocean Coast Manag 53:209-217

Belfiore S (2000) Recent developments in coastal management in the European Union. Ocean Coast Manag 43: 123-135

Belfiore $\mathrm{S}$, Barbière $\mathrm{J}$, Bowen $\mathrm{R}$, Cicin-Sain $\mathrm{B}$ and others (2006) A handbook for measuring the progress and outcomes of integrated coastal and ocean management. In: Heileman S (ed) IOC manuals and guides, 46. ICAM Dossier 2. UNESCO, Paris, p 1-215

> Bidone ED, Lacerda LD (2004) The use of DPSIR framework to evaluate sustainability in coastal areas. Case study: Guanabara Bay basin, Rio de Janeiro, Brazil. Reg Environ Change 4:5-16

Billé R (2007) A dual-level framework for evaluating integrated coastal management beyond labels. Ocean Coast Manag 50:796-807

Bockstael N, Costanza R, Strand I, Boynton W, Bell K, Wainger L (1995) Ecological economic modeling and valuation of ecosystems. Ecol Econ 14:143-159

Boissonnas J, Connolly N, Mantoura F, D'Ozouville L (2002) Integrating marine science in Europe. European Science Foundation Marine Board, Strasbourg

Borja A (2006) The new European Marine Strategy Directive: difficulties, opportunities, and challenges. Mar Pollut Bull 52:239-242

> Borja A, Collins M (2009) Regional seas integrative studies, as a basis for an ecosystem-based approach to management: the case of the Bay of Biscay. Cont Shelf Res 29:951-956

Borja A, Bricker SB, Dauer DM, Demetriades NT and others (2008) Overview of integrative tools and methods in assessing ecological integrity in estuarine and coastal systems worldwide. Mar Pollut Bull 56:1519-1537

Borja A, Elliott M, Carstensen J, Heiskanen AS, van de Bund W (2010) Marine management-towards an integrated implementation of the European Marine Strategy Framework and the Water Framework Directives. Mar Pollut Bull 60:2175-2186

Bowen RE, Riley C (2003) Socio-economic indicators and inte- grated coastal management. Ocean Coast Manag 46: 299-312

Breton F (2006) Report on the use of the ICZM indicators from the WG-ID. A contribution to the ICZM evaluation. Version 1. 'Indicators and data' working group (WG-ID) of the European ICZM expert group. Universitat Antònoma de Barcelona and European Environment Agency. Available at http://ec.europa.eu/environment/iczm/pdf/report_wgid.pdf

Browman HI, Stergiou KI (eds) (2005) Politics and socio-economics of ecosystem-based management of marine resources. Mar Ecol Prog Ser 300:241-296

Burbridge PR (1997) A generic framework for measuring success in integrated coastal management. Ocean Coast Manag 37:175-189

Cao W, Wong MH (2007) Current status of coastal zone issues and management in China: a review. Environ Int 33: 985-992

Cheong SM (2008) A new direction in coastal management. Mar Policy 32:1090-1093

Cicin-Sain B, Knecht RW (1998) Integrated coastal and ocean management: concepts and practices. Island Press, Washington, DC

Clark JR (1996) Coastal zone management handbook. Lewis/CRC Publishers, Boca Raton, FL

Cömert Ç, Akýncý H, Sahin N, Bahar O (2008) The value of marine spatial data infrastructure for integrated coastal zone management. Fresenius Environ Bull 17:2240-2249

Cordah Ltd (2001) Indicators to monitor the progress of integrated coastal zone management: a review of worldwide practice. Scottish Executive Central Research Unit, Edinburgh

Costanza R, Farley J (2007) Ecological economics of coastal disasters: introduction to the special issue. Ecol Econ 63:249-253

Crowder L, Norse E (2008) Essential ecological insights for marine ecosystem-based management and marine spatial planning. Mar Policy 32:772-778

> Cruz I, McLaughlin RJ (2008) Contrasting marine policies in the United States, Mexico, Cuba and the European Union: searching for an integrated strategy for the Gulf of Mexico region. Ocean Coast Manag 51:826-838

Day JC (2002) Zoning - lessons from the Great Barrier Reef Marine Park. Ocean Coast Manag 45:139-156

Deboudt P, Dauvin JC, Lozachmeur O (2008) Recent developments in coastal zone management in France: the transition towards integrated coastal zone management (19732007). Ocean Coast Manag 51:212-228

> Defeo O, McLachlan A, Schoeman DS, Schlacher TA and others (2009) Threats to sandy beach ecosystems: a review. Estuar Coast Shelf Sci 81:1-12

DEFRA (Department for Environment, Food and Rural Affairs) (2010) United Kingdom report to the European Commission. Implementation of the ICZM Recommendation 2006 - 2010. DEFRA, London

DEFRA (2008) A strategy for promoting an integrated approach to the management of coastal areas in England. DEFRA, London

Dempster T, Sanchez-Jerez P (2008) Aquaculture and coastal space management in Europe: an ecological perspective. In: Holmer M, Black K, Duarte CM, Marbà N, Karakassis I (eds) Aquaculture in the ecosystem. Springer

Dennison WC (2008) Environmental problem solving in coastal ecosystems: a paradigm shift to sustainability. Estuar Coast Shelf Sci 77:185-196

Diedrich A, Tintoré J, Navinés F (2010) Balancing science and society through establishing indicators for integrated coastal zone management in the Balearic Islands. Mar 
Policy 34:772-781

DOENI (Department of the Environment in Northern Ireland) (2006) An integrated coastal zone management strategy for Northern Ireland 2006-2026. DOENI, Belfast

> Douvere F (2008) The importance of marine spatial planning in advancing ecosystem-based sea use management. Mar Policy 32:762-771

Douvere F, Ehler CN (2009) New perspectives on sea use management: initial findings from European experience with marine spatial planning. J Environ Manag 90:77-88

Douvere F, Ehler C (2010) Ecosystem-based marine spatial management: an evolving paradigm for the management of coastal and marine places. Ocean Yearb 23:1-26

$>$ Douvere F, Maes F, Vanhulle A, Schrijvers J (2007) The role of marine spatial planning in sea use management: the Belgian case. Mar Policy 31:182-191

Drechsler M, Watzold F (2007) Ecological-economic modelling for the sustainable use and conservation of biodiversity. Ecol Econ 62:203-206

> Drechsler M, Grimm V, Mysiak J, Watzold F (2007) Differences and similarities between ecological and economic models for biodiversity conservation. Ecol Econ 62: 232-241

Ducrotoy JP, Elliott M (2006) Recent developments in estuarine ecology and management. Mar Pollut Bull 53:1-4

Ducrotoy JP, Elliott M (2008) The science and management of the North Sea and the Baltic Sea: natural history, present threats and future challenges. Mar Pollut Bull 57:8-21

EC (European Commission) (2008a) Commission decision 2008/915/EC of 30 October 2008: establishing, pursuant to Directive 2000/60/EC of the European Parliament and of the Council, the values of the Member State monitoring system classifications as a result of the intercalibration exercise. Off J Eur Union L332:20-44

EC (2008b) Communication from the Commission: roadmap for maritime spatial planning: achieving common principles in the EU. Commission of the European Communities, Brussels

Egoh B, Rouget M, Reyers B, Knight AT, Cowling RM, van Jaarsveld AS, Welz A (2007) Integrating ecosystem services into conservation assessments: a review. Ecol Econ 63:714-721

Ehler CN (2003) Indicators to measure governance performance in integrated coastal management. Ocean Coast Manag 46:335-345

Ehler C, Douvere F (2009) Marine spatial planning: a step-bystep approach toward ecosystem-based management. Intergovernmental Oceanographic Commission on Man and the Biosphere Programme. IOC manual and guides No. 53, ICAM Dossier No. 6. UNESCO, Paris

Ehler CN, Cicin-Sain B, Knecht R, South R, Weiher R (1997) Guidelines to assist policy makers and managers of coastal areas in the integration of coastal management programs and national climate-change action plans. Ocean Coast Manag 37:7-27

Elliott M (2002) The role of the DPSIR approach and conceptual models in marine environmental management: an example for offshore wind power. Mar Pollut Bull 44:iii-vii

Enemark J (2005) The Wadden Sea protection and management scheme-towards an integrated coastal management approach? Ocean Coast Manag 48:996-1015

Eremina TR, Stetsko EV (2003) Legal provision for integrated coastal zone management. Textbook based on a UNESCO/CSI related project on Sustainable Coastal Development in the White Sea-Barents Sea Region. Russian State Hydrometeorological University (RSHU). Available at www.unesco.org/csi/act/russia/legalpro1.htm (accessed
8 October 2010)

Fabbri KP (1998) A methodology for supporting decision making in integrated coastal zone management. Ocean Coast Manag 39:51-62

FAO (Food and Agriculture Organization of the United Nations) (2007) The state of world fisheries and aquaculture, 2006. FAO Fisheries and Aquaculture Department, Rome

Farber S, Costanza R, Childers DL, Erickson J and others (2006) Linking ecology and economics for ecosystem management. Bioscience 56:121-133

Ferreira JG, Nobre AM, Simas TC, Silva MC and others (2006) A methodology for defining homogeneous water bodies in estuaries - application to the transitional systems of the EU Water Framework Directive. Estuar Coast Shelf Sci 66:468-482

Ferreira JG, Hawkins AJS, Monteiro P, Moore H and others (2008) Integrated assessment of ecosystem-scale carrying capacity in shellfish growing areas. Aquaculture 275: $138-151$

Fluharty D (2005) Evolving ecosystem approaches to management of fisheries in the USA. Mar Ecol Prog Ser 300: $248-253$

Foley MM, Halpern BS, Micheli F, Armsby MH and others (2010) Guiding ecological principles for marine spatial planning. Mar Policy 34:955-966

Forst MF (2009) The convergence of integrated coastal zone management and the ecosystems approach. Ocean Coast Manag 52:294-306

Fulton EA, Smith ADM, Johnson CR (2003) Effect of complexity on marine ecosystem models. Mar Ecol Prog Ser 253:1-16

Gallagher A (2010) The coastal sustainability standard: a management systems approach to ICZM. Ocean Coast Manag 53:336-349

> Gibson J (2003) Integrated coastal zone management law in the European Union. Coast Manag 31:127-136

> Greiner R (2004) Systems framework for regional-scale integrated modelling and assessment. Math Comput Simul 64: $41-51$

> Grumbine ER (1994) What is ecosystem management? Conserv Biol 8:27-38

Hale LZ (2000) Achieving integration in coastal management: the challenge of linking national and local levels of government. Korea Obs 30:671-690

Halpern BS, McLeod KL, Rosenberg AA, Crowder LB (2008a) Managing for cumulative impacts in ecosystem-based management through ocean zoning. Ocean Coast Manag 51:203-211

- Halpern BS, Walbridge S, Selkoe KA, Kappel CV and others (2008b) A global map of human impact on marine ecosystems. Science 319:948-952

- Hardman-Mountford NJ, Allen JI, Frost MT, Hawkins SJ and others (2005) Diagnostic monitoring of a changing environment: an alternative UK perspective. Mar Pollut Bull 50:1463-1471

Harris G (2002) Integrated assessment and modelling: an essential way of doing science. Environ Model Softw 17: 201-207

HELCOM (Helsinki Commission) (2007) The HELCOM Baltic Sea action plan. HELCOM Ministerial Meeting, Krakow, Poland, 15 November 2007. Available at www.helcom. fi/BSAP/ActionPlan/en_GB/ActionPlan/

> Hershman MJ, Good JW, Bernd-Cohen T, Goodwin RF, Lee V, Pogue P (1999) The effectiveness of coastal zone management in the United States. Coast Manag 27:113-138

Hoffmann J (2009) Indicators for an ICZM. Experience with a 
problem-oriented approach. J Coast Conserv 13:141-150 doi:10.1007/s11852-009-0052-0

Hofmann J, Behrendt H, Gilbert A, Janssen R and others (2005) Catchment-coastal zone interaction based upon scenario and model analysis: Elbe and the German Bight case study. Reg Environ Change 5:54-81

- Humphrey S, Burbridge P, Blatch C (2000) US lessons for coastal management in the European Union. Mar Policy 24:275-286

Imperial MT, Hennessey TM (1996) An ecosystem-based approach to managing estuaries: an assessment of the National Estuary program. Coast Manag 24:115-139

Kay R, Eliot I, Panizza V, Donaldson B (1997) Reforming coastal management in Western Australia. Ocean Coast Manag 35:1-29

Kearney J, Berkes F, Charles A, Pinkerton E, Wiber M (2007) The role of participatory governance and communitybased management in integrated coastal and ocean management in Canada. Coast Manag 35:79-104

Kiousopoulos J (2008) Methodological approach of coastal areas concerning typology and spatial indicators, in the context of integrated management and environmental assessment. J Coast Conserv 12:19-25

Knecht RW, Cicin-Sain B, Fisk GW (1996) Perceptions of the performance of state coastal zone management programs in the United States. Coast Manag 24:141-163

Knecht RW, Cicin-Sain B, Fisk GW (1997) Perceptions of the performance of state coastal zone management programs in the United States. II. Regional and state comparisons. Coast Manag 25:325-343

Koch EW, Barbier EB, Silliman BR, Reed DJ and others (2009) Non-linearity in ecosystem services: temporal and spatial variability in coastal protection. Front Ecol Environ 7: 29-37

Krishnamurthy RR, Kannen A, Ramanathan AL, Tinti S and others (eds) (2008) Integrated coastal zone managementthe global challenge. Research Publishing, Singapore, Chennai

Lal P (2003) Economic valuation of mangroves and decisionmaking in the Pacific. Ocean Coast Manag 46:823-844

Lau M (2005) Integrated coastal zone management in the People's Republic of China - an assessment of structural impacts on decision-making processes. Ocean Coast Manag 48:115-159

Ledoux L, Turner RK (2002) Valuing ocean and coastal resources: a review of practical examples and issues for further action. Ocean Coast Manag 45:583-616

Lester SE, McLeod KL, Tallis H, Ruckelshaus M and others (2010) Science in support of ecosystem-based management for the US west coast and beyond. Biol Conserv 143: 576-587

Lewis RR III, Clark PA, Fehring WK, Greening HS, Johansson RO, Paul RT (1999) The rehabilitation of the Tampa Bay Estuary, Florida, USA, as an example of successful integrated coastal management. Mar Pollut Bull 37:468-473

Luiten H (1999) A legislative view on science and predictive models. Environ Pollut 100:5-11

MA (Millennium Ecosystem Assessment) (2005) Global assessment reports, Vol 1: current state and trends. Chapter 19: coastal systems. Island Press, Washington, DC

Martínez ML, Intralawan A, Vázquez G, Pérez-Maqueo O, Sutton P, Landgrave R (2007) The coasts of our world: ecological, economic and social importance. Ecol Econ 63:254-272

- McCreary S, Gamman J, Brooks B, Whitman L and others (2001) Applying a mediated negotiation framework to integrated coastal zone management. Coast Manag 29: $183-216$
McFadden L (2007) Governing coastal spaces: the case of disappearing science in integrated coastal zone management. Coast Manag 35:429-443

McLeod K, Leslie H (2009) Ecosystem-based management for the oceans. Island Press, Washington, DC

> McNeil TC, Rousseau FR, Hildebrand LP (2006) Communitybased environmental management in Atlantic Canada: the impacts and spheres of influence of the Atlantic coastal action program. Environ Monit Assess 113:367-383

McNie EC (2007) Reconciling the supply of scientific information with user demands: an analysis of the problem and review of the literature. Environ Sci Policy 10:17-38

Murawski SA (2007) Ten myths concerning ecosystem approaches to marine resource management. Mar Policy 31:681-690

Neal C, Leeks GJL, Millward GE, Harris JRW, Huthnance JM, Rees JG (2003) Land-ocean interaction: processes, functioning and environmental management from a UK perspective: an introduction. Sci Total Environ 314-316:3-11

Nijkamp P, van den Bergh JCJM (1997) New advances in economic modelling and evaluation of environmental issues. Eur J Oper Res 99:180-196

> Nobre AM (2009) An ecological and economic assessment methodology for coastal ecosystem management. Environ Manag 44:185-204

Nobre AM, Ferreira JG (2009) Integration of ecosystem-based tools to support coastal zone management. J Coast Res SI56:1676-1680

> Nobre AM, Ferreira JG, Newton A, Simas T, Icely JD, Neves $R$ (2005) Management of coastal eutrophication: integration of field data, ecosystem-scale simulations and screening models. J Mar Syst 56:375-390

Nobre AM, Musango JK, de Wit MP, Ferreira JG (2009) A dynamic ecological-economic modeling approach for aquaculture management. Ecol Econ 68:3007-3017

Nobre AM, Ferreira JG, Nunes JP, Yan X and others (2010a) Assessment of coastal management options by means of multilayered ecosystem models. Estuar Coast Shelf Sci 87: $43-62$

Nobre AM, Robertson-Andersson D, Neori A, Sankar K (2010b) Ecological-economic assessment of aquaculture options: comparison between abalone monoculture and integrated multi-trophic aquaculture of abalone and seaweeds. Aquaculture 306:116-126

NRMMC (National Resource Management Ministerial Council) (2006) National cooperative approach to integrated coastal zone management. Framework and implementation plan. NRMMC, Department of the Environment and Heritage, Canberra

> Olsen SB (2003) Frameworks and indicators for assessing progress in integrated coastal management initiatives. Ocean Coast Manag 46:347-361

Olsen S, Tobey J, Kerr M (1997) A common framework for learning from ICM experience. Ocean Coast Manag 37:155-174

Peirce M (1998) Computer-based models in integrated environmental assessment. Tech Rep no. 14. prepared by AEA Technology plc for the European Environment Agency, Warrington

PEMSEA (2003) The development of national coastal and marine policies in the People's Republic of China: a case study. PEMSEA Tech Rep No. 7. Global Environment Facility/United Nations Development Programme/International Maritime Organization Regional Programme on Building Partnerships in Environmental Management for the Seas of East Asia (PEMSEA), Quezon City

Pickaver A (2003) Integrated coastal zone management in the Baltic States - state of the art report. EUCC - The Coastal 
Union, Available at www.ikzm-d.de/infos/pdfs/150_EUCC _Baltic_ICZM_State_of_Art_1__converted_.page01_-_19. pdf

Pickaver AH, Gilbert C, Breton F (2004) An indicator set to measure the progress in the implementation of integrated coastal zone management in Europe. Ocean Coast Manag 47:449-462

Queffelec B, Cummins V, Bailly D (2009) Integrated management of marine biodiversity in Europe: perspectives from ICZM and the evolving EU Maritime Policy framework. Mar Policy 33:871-877

Rönnbäck P, Kautsky N, Pihl L, Troell M, Söderqvist T, Wennhage H (2007) Ecosystem goods and services from Swedish coastal habitats: identification, valuation, and implications of ecosystem shifts. Ambio 36:534-544

Rupprecht Consult, IOI (International Ocean Institute) (2006) Evaluation of integrated coastal zone management (ICZM) in Europe. Final report. European Commission, Cologne

Sardá R, Avila C, Mora J (2005) A methodological approach to be used in integrated coastal zone management processes: the case of the Catalan Coast (Catalonia, Spain). Estuar Coast Shelf Sci 62:427-439

Scheren PAGM, Kroeze C, Janssen FJJG, Hordijk L, Ptasinski KJ (2004) Integrated water pollution assessment of the Ebrie Lagoon, Ivory Coast, West Africa. J Mar Syst 44:1-17

Scottish Executive (2005) Seas the opportunity: a strategy for the long-term sustainability of Scotland's coasts and seas. Scottish Executive, Edinburgh

Seim HE, Fletcher M, Mooers CNK, Nelson JR, Weisberg RH (2009) Towards a regional coastal ocean observing system: an initial design for the Southeast Coastal Ocean Observing Regional Association. J Mar Syst 77:261-277

Shipman B, Stojanovic T (2007) Facts, fictions, and failures of integrated coastal zone management in Europe. Coast Manag 35:375-398

Slocombe D (1993) Environmental planning, ecosystem science, and ecosystem approaches for integrating environment and development. Environ Manag 17:289-303

Slocombe DS (1998) Lessons from experience with ecosystem-based management. Landsc Urban Plan 40:31-39

Smith HD, Potts J (2005) Managing Britain's marine and coastal environment, towards a sustainable future. Routledge and the National Maritime Museum, London

Soto D, Aguilar-Manjarrez J, Hishamunda N (eds) (2008) Building an ecosystem approach to aquaculture.
FAO/Universitat de les Illes Balears expert workshop, 711 May 2007, Palma de Mallorca, Spain. FAO Fisheries and Aquaculture Proceedings, No. 14. FAO, Rome

Stanners D, Bosch P, Dom A, Gabrielsen P and others 2008. Frameworks for environmental assessment and indicators at the EEA. In: Hak T, Moldan B, Dahl AL (eds) Sustainability indicators: a scientific assessment. Island Press, Washington, DC, p 127-144

Stojanovic TA, Ballinger RC (2009) Integrated coastal management: a comparative analysis of four UK initiatives. Appl Geogr 29:49-62

Stojanovic T, Ballinger RC, Lalwani CS (2004) Successful integrated coastal management: measuring it with research and contributing to wise practice. Ocean Coast Manag 47: 273-298

Tallis H, Levin PS, Ruckelshaus M, Lester SE, McLeod KL, Fluharty DL, Halpern BS (2010) The many faces of ecosystem-based management: making the process work today in real places. Mar Policy 34:340-348

- Taveira-Pinto F (2004) The practice of coastal zone management in Portugal. J Coast Conserv 10:147-158

> Tol R, Vellinga P (1998) The European Forum on Integrated Environmental Assessment. Environ Model Assess 3: 181-191

- Turner RK (2000) Integrating natural and socio-economic science in coastal management. J Mar Syst 25:447-460

> van Alphen J (1995) The Voordelta integrated policy plan: administrative aspects of coastal zone management in the Netherlands. Ocean Coast Manag 26:133-150

Van Kouwen F, Dieperink C, Schot P, Wassen M (2008) Applicability of decision support systems for integrated coastal zone management. Coast Manag 36:19-34

Veloso-Gomes F, Taveira-Pinto F (2003) Portuguese coastal zones and the new coastal management plans. J Coast Conserv 9:25-34

WAG (Welsh Assembly Government) (2007) Making the most of Wales' coast - the integrated coastal zone management strategy for Wales. Countryside Access and Sponsorship, Environment Conservation and Management Division, Cardiff

Westmacott S (2001) Developing decision support systems for integrated coastal management in the tropics: Is the ICM decision-making environment too complex for the development of a useable and useful DSS? J Environ Manag 62: 55-74 